\title{
The Social and Solidarity Economy: an opportunity for young women's work transitions?
}

\author{
Roger Soler-i-Martí \\ roger.soler@upf.edu \\ Andreu Camprubí Trepat \\ andreu@elrisell.cat \\ Ester Oliveras \\ ester.oliveras@upf.edu \\ Mireia Sierra Andrés \\ mireia.sierra@ub.edu
}

\begin{abstract}
(100-150 words)
This article analyses to what extent the Social and Solidarity Economy (SSE), the aim of which is to prioritize people's needs and well-being, can offer young people education-to-work transitions conditions and opportunities which are different from those in the conventional economy. The very nature of the SSE means that it is especially suitable for challenging gender inequality and proves to be exceptionally useful for testing feminist economics. Against a backdrop of economic crisis, the SSE has shown greater resilience when compared to other sectors, although it is still not widespread. To examine how the SSE can improve young women's experiences and labour trajectories, this article analyses working conditions, job satisfaction and gender roles in school-towork transitions of young women in the SSE in Catalonia. Results show that the collective and value-driven nature of the SSE entails a specific awareness and commitment that empower young women's transitions experiences and expectations.
\end{abstract}

Key words: School-to-work transitions, Women, Social and solidarity economy, Feminist economics, Youth trajectories, Economic crisis, Catalonia, Spain 


\section{Introduction}

The 2008 Financial Crisis meant that an entire generation of young people started their career trajectory in times of great uncertainty and precarity, thus taking the tendency of vulnerability and de-standardization of young people's life transitions to new levels (Aassve, Cottini, \& Vitali, 2013; Serracant, 2015; France, 2016). Young women faced additional difficulties in the form of gender discrimination and, more notably, the impact of unequal distribution of reproductive and caregiving tasks at a key point in their professional trajectories (Chacaltana et al 2020; Moreno 2013). As another global economic crisis following the COVID-19 pandemic is looming, the impact on these generations can be especially devastating due to the 'scarring effect' of unemployment, job precarity and instability during the first years of medium- and long-term career paths (Nordström Skans, 2011; Schmillen \& Umkehrer, 2017).

Within the concept of the Social and Solidarity Economy (SSE), non-governmental economic initiatives which aim to prioritize people's needs over economic benefits are grouped together in more inclusive and democratic forms of organization (Utting, 2015). The exact nature of the Social and Solidarity Economy and the form it takes is significantly different according to the country, but it is nevertheless a strategic sector to consider in terms of the future of work (Borzaga, Salvatori, \& Bodini, 2017), for more reasons than its resilience in times of economic crisis (Monzón \& Chaves, 2012).

The extensive research on young people's transition into the labour market has paid little attention to the potential advantages that alternative sectors like the SSE have over the traditional economy. This article analyses the experiences and expectations of young women in Catalonia as they start their trajectories within the framework of the SSE. It uses a mixed-methods approach and attempts to answer to what extent and in what ways the SSE contributes to improving women's experiences of work at the time of joining the job market. To do so, three key dimensions of youth trajectories are analysed: working conditions and the role of precarity; job satisfaction and value and the gender dimension; and, most notably, achieving a good work-life balance.

\section{Economic crisis, transitions into the job market and gender}

The 2008 financial crisis had an enormous impact on the youth labour market and the transitions within it, which subsequently altered the strategies, experiences and future expectations of this generation of young people entirely. The effect on youth employment was not uniform across Europe due to the different characteristics of the countries' labour markets (Dietrich \& Möller, 2016). The impact was especially severe in countries which had implemented austerity measures that implied a drastic reduction in company labour costs based on the destruction of temporary employment. This was the case in southern Europe and the effect was compounded because 
temporality is strongly associated with youth in Mediterranean countries (Cachón, 2004). In addition to this, there is also little institutional support and few public policies related to school-towork transitions in these countries, particularly in Spain (Pastore 2015). Here, the unemployment rate for 20- to 24-year-olds was around 50\% between 2012 and 2014. Other youth transitions were also affected: they took longer, phenomena of reversibility increased, and youth trajectories became increasingly vulnerable (Serracant, 2015). That said, job insecurity is not limited to mercantile roles: it crosses over into other areas of life (Batchelor, Fraser, Whittaker, \& Li, 2020; Miguel Carmo, Cantante, \& de Almeida Alves, 2014) and also affects the creation of expectations and plans for the future (Leccardi, 2012). Through their analysis of trajectories during the crisis, Verd, Barranco, \& Bolíbar, (2019) show how young people, and especially those with the most vulnerable profiles, are trapped in a cycle of unskilled roles and periods of unemployment with the result that this perpetuates the economic and social division of the population (Fenton \& Dermott, 2006).

Gender inequality in youth trajectories becomes most apparent in one key aspect: reproduction. At the beginning of career trajectories, any differences are mitigated. The age at which young people join the labour market, for example, is similar for both men and women. However, differences emerge due to motherhood because of the need to reconcile work and family obligations, the latter of which still fall on women to take responsibility for (Craig, 2012; Chacaltana, 2020; Moreno, 2013). This becomes evident when the women who are more likely to find a job, especially for parttime roles or those in the tertiary sector, are those who are young, with a high level of education and without children (Millán-Vázquez de la Torre, Santos-Pita, \& Pérez-Naranjo, 2015). Walsh, Keary, \& Gleeson, (2019) demonstrated in a longitudinal study of three generations of women how social expectations regarding gender affect patterns of work transition generation after generation.

Thus, from the onset, feminist economy has highlighted how classic economy does not consider reproduction and caregiving as a necessary part of productive activity and places them outside the market economy and in the home environment (Waring, 1990; Carrasco, 2006). As noted by Pigou (1920) differences in income at a national level are produced by a meal in a restaurant but not by a home-cooked meal. This limited definition of work, associated with the perception of monetary remuneration, is detrimental to women, upon whom the work associated with reproductive and unpaid activities usually falls. The feminist economy emerged due to the necessity to move towards an economy that puts 'life at the centre', makes the care work visible, incorporates the analysis of unequal gender dimensions and carries an implicit commitment to contribute to the construction of a fair socioeconomic system (Carrasco, 2006; Carrasco y Díaz, 2017).

From this feminist perspective, it is essential to include reproductive and caregiving tasks in the analysis of youth labour trajectories as it is vital in maintaining, sustaining and ensuring the continuation of productive work (Federici, 2018). In terms of the decisions, opportunities, constrictions, difficulties and expectations that shape school-to-work transitions, the reproductive and caregiving dimension plays a crucial role and it is at the centre of inequalities in the labour market. 


\section{The Social and Solidarity Economy as an opportunity?}

The Social and Solidarity Economy (SSE) encompasses a wide range of organizations that aim to prioritize the well-being of people and society. Although currently there is no clear delimitation of the organizations which form part of it. TheInternational Labour Organization states that the SSE includes cooperatives, mutual societies, associations, foundations and social companies which produce goods and offer services and knowledge while pursuing social and economic objectives and promoting solidarity (Fonteneau et al., 2011).

The SSE covers a wide and heterogenous spectrum of legal entities, with the result that a definition based on its legal forms does little to understand the concept itself and it is therefore more useful to consider the practices, values and principles in order to understand what the SSE is. Likewise, it cannot be defined by the companies' corporate purpose because although many focus on the provision of welfare and inclusion services, SSE entities can be found in all activity sectors. That said, a large proportion of these currently operate within the service sector and there is a lack of representation in other sectors such as industry and technology. The International Labour Organization (Borzaga et al., 2017) identifies a series of characteristics for the definition of SSE entities that go beyond their legal form. They argue that most emerged within a community framework in response to the community's needs or opportunities. The creation and start-up stages are based on voluntary work and they are companies that are not oriented towards receiving benefits but rather being used as an instrument to satisfy the needs of their members and/or communities. Ownership is usually collective and they try to apply more democractic and inclusive forms of governance.

The organizations that are part of the SSE are capable, to some extent, of absorbing the negative effects of economic crises in that they look for ways to adapt and maintain jobs. They act acting in a countercyclical manner, any limitations they have in terms of dimension, economic sectors, the type of employment offered and the need for finance especially during the initial stages are all usually compensated for by overworking (Bergeron \& Healy, 2015; Karaphillis \& Lake, 2017). Despite challenges when assessing any economic impact (Steven \& Kimbery, 2007), according to the European Economic and Social Committee (Monzón \& Chaves 2012), the 2008 Financial Crisis affected the SSE to a lesser extent because it is based on real and local economy and not on the financial economy. This was seen in the case of Spain in that unemployment in cooperatives increased by just $9 \%$ between 2008 and 2012 while the global increase in the private sector was $19 \%$. In factm in the last 15 years, the SSE has brought about a $20 \%$ increase in employment (Monzón \& Chaves, 2016). In a comparative study, Kalogeraki, Papadaki, \& Pera Ros, (2018) compare the response of the SSE to the economic crisis in three European countries. Greece, strongly affected by the crisis and with little tradition in SSE, experienced a strong expansion in this type of organization in response to the social and economic needs that were not being addressed by the State. Spain, with a longer tradition of SSE, saw a move from traditional companies to cooperatives, which were in turn democratically managed by workers or newly-created as a form of group self-employment. This response in the SSE was noticed by the European Union, who, in 2012, launched the Initiative for Social Entrepreneurship with the aim of facilitating the development of this type of business project. In addition to the potential of offering greater solidarity and more job 
security in times of economic crisis, Onyx \& Maclean (1996) point out how this economy with social value constitutes a work option that is personally challenging, makes significant social impact, and offers a means to achieve a better work-life balance, all of which are characteristics that women value the most. Furthermore, Huysentruyt (2014) confirms that there is greater participation of women in non-profit economic sectors. A survey of 192 women who lead social enterprises was conducted at a European level. It revealed that for $63 \%$ of the participants, their main motivation is to have a positive impact on society (Py \& Berthélemy, 2019). All of this evidence shows how the SSE can be an attractive professional opportunity for women, both from the point of view of personal work motivation as well as for the possibility of maintaining a more satisfactory work-life balance. Recognising the social impact and a feeling of belonging are essential in the SSE and these also reflect aspects found in the feminist economy in that it prioritises working practices that allow workers to strike a balance between work and other aspects of their lives by advocating shared responsibility of productive and reproductive tasks (Mansilla, Grenzner, \& Alberich, 2014).

Despite the extensive literature on school-to-work transitions, there are no academic papers which analyse how labour transitions take place in the SSE and the way in which this can help improve career trajectories for young women facing an uncertain future.

\section{Methodology}

In order to explore whether the SSE has provided opportunities for young women to improve their experience and expectations of youth work transitions in a context of economic crisis, it was decided that a sequenced mixed-methods and a participatory strategy would be most appropriate. Mixed-methods strategies (the combination of qualitative and quantitative research approaches) allow for a deeper understanding and the possibility to corroborate the phenomena analysed (Johnson, J. Onwuegbuzie, \& A Turner, 2007). For this study in particular, a qualitative approach was essential in being able to analyse the subjective experience and expectations linked to youth labour trajectories. Thus, based on the first round of qualitative data, a survey was designed with the aim of measuring and corroborating the relationships that were seen in prior interviews and discussion groups.

Collecting this qualitative data involved carrying out 18 in-depth interviews and 3 focus groups with young workers from different sectors of the SSE and areas of Catalonia were carried out between May and September 2018. This region is of particular interest because it has the highest number of cooperatives out of all the Autonomous Communities in Spain, representing 19.8\% in 2018 and has the fourth largest workforce (COCETA, 2018). The script and the dynamics of both the interviews and the discussion groups aimed to elicit information about reconstructing participants' own career transitions from the time they finished studying to the present day. The main focus was to find out how they came to work in the SSE, their experiences (both real and subjective), their future expectations and their own critical evaluations of their trajectories. 
Consistent with the exploratory sequential mixed methods approach (Bazeley, 2009; Cameron, 2009), for a better integration of qualitative and quantitative elements, after completing the collection of qualitative data, a questionnaire was designed with the aim of measuring and validating preliminary results obtained from interviews and focus groups. This questionnairewas in the form of an online survey for women from 18 to 39 years of age working in a SSE organisation. The survey retrospectively asked about the participants' educational and labour trajectories, meaning that the information collected is related to the participants' youth that corresponds to the economic crisis and post-crisis period.

The survey was completed by a non-probability sample. This was achieved by the umbrella organisations in the SSE distributing the survey to all their individual members. Due to the low number of potential participants, an additional snowball recruitment sampling strategy was adopted (Browne, 2005) asking respondents to share the online questionnaire with other potential respondents. The fieldwork for the survey lasted from October to December 2018. The final sample of the 302 cases that remained after discarding incomplete responses or those from participants not matching the age profile or without a link to the SSE.

To enhance the impact and validity of the results, the research also incorporated a participatory dimension. Participatory investigation, wherein the population or community that is the object of study is involved in one or several phases of the research, can pursue different objectives from a methodological point of view. For this study, the emphasis was on ensuring that young women linked to the SSE participated in the data analysis, which is one of the phases of study where the potential of participatory investigation has been less explored (Nind, 2011). At different parts of the research process, three participatory sessions were held. During these, young women linked to the SSE from different fields were presented with results and subsequently given time for reflection and deliberation and to interpret the data. This approach to participatory data analysis was included not only to improve the study's social impact but also enrich the knowledge generated during dialogue in terms of structured information arising out of the research process as well as the participants' direct experiential knowledge (Whyte, 1989). Thus, a significant part of the contributions and interpretations of this article have arisen from these milieus of collective deliberation. The result of this is that it provides an extra level of corroboration and external validation of results in addition to the sequential mixed-methods approach.

\section{Results and discussion}

Before turning to the analysis of the transition experiences of young women in the SSE, it is necessary to point out two key aspects about the social profile of the participants of the survey and the qualitative research, which is also representative of the profile of the young people linked to the SSE. First, they are middle-class young women with a university education (making up 73\% of the survey sample). They, therefore, represent the trajectories of those who have been referred to as the 'missing middle', indicating to the lack of attention research pays to these average youth paths 
while focusing more on extremes (Roberts, 2011; Woodman, 2013). In Spain, which is similar to the case in Portugal as shown by Cairns, Growiec, \& de Almeida Alves (2014), these 'missing middle' university trajectories are marked by a great deal of confusion with regard to the future as a result of the economic crisis. The second crucial characteristic of the profile of the young women linked to the SSE to highlight is their associative trajectory: nearly all of the survey sample stated that they were involved in some kind of association during their youth. The relevance of the associative trajectory gains importance when considering satisfaction and job commitment as seen below.

To study the experience of young women in the SSE, three key aspects are analysed: working conditions of women in the SSE with a focus on experience with precarity; job valuation within the framework of the SSE and satisfaction in relation to personal values; and the gender dimension and experience of gender roles and practices in the SSE workplace during their work transitions.

\section{Working conditions and precarity}

It is especially difficult to compare working conditions in the SSE and the conventional economy based on official statistical sources. In Spain, like in the rest of Europe, these data do not tend to be officially collected nor is the sample size big enough to make comparisons. Publications and research related to the SSE focus on analysing cooperative legal formulae without them being compared to others, thus providing a case in point for these difficulties (Borzaga et al., 2017). At a comparative level, studies carried out in Italy show that the value-added percentage that workers in Italian cooperatives receive is much higher than in any other type of business (Borgaza 2015). Furthermore, that nearly $80 \%$ of those employed by Italian cooperatives had a permanent contract (Carini y Fontanari, 2017), a figure that increased by 8\% between 2008 and 2013 (Borgaza, 2015). In Spain, and in Catalonia in particular, there are several initiatives which collect data on working conditions in the SSE ${ }^{\mathrm{i}}$. Although it is not yet possible to draw firm conclusions, these data suggest that much like in Italy, there is greater tendency towards job stability and quality in this context.

However, the qualitative data from the research as well as the participatory discussions have emphasised situations of precarity in projects within the SSE and in managing this precarity in a context of economic crisis. The survey of young women linked to the SSE included various questions on working conditions. The survey characteristics mean that it is not possible to compare with official data but they do reveal how this precarity is distributed. To analyse this, a synthetic working conditions index was created. This index collects information on the type of contract, weekly hours, multiple jobs and income $e^{\mathrm{ii}}$.

This index means it is possible to see that there is a positive correlation between the age of the social economy entity and working conditions $\mathrm{s}^{\mathrm{iii}}$. This correlation shows that the most precarious conditions are found during a project's initial years. This is a logical and common occurrence in companies in the conventional economy given that at the beginning of a project there is usually less solvency and workers are more likely to be subjected to worse conditions (Nyström, 2019). 
However, a common trend in projects in the process of consolidation is that the promoters of the same, the founding partners, not only invest their savings or advances in benefits but also hours of dedication with no remuneration. When the project begins to provide economic benefits, priority is given to guaranteeing satisfactory working conditions for the workers to the detriment of the partner's conditions.

"We as partners receive salaries that are about $60 \%$ of what we would normally agree to work for. This means that the workers have better working conditions, perhaps even better than the ones laid out in the labour agreement. We try to promote and defend good working conditions, even if they are better for the workers than for the partners." [Discussion group. Founding partner]

Figure 1 shows the average value of the working conditions index according to the nature of the link that respondent has with the SSE. Female founding partners experience worse working conditions than the rest of the female workers and far worse conditions than working partners who were not involved in the process of founding the projects.

\section{[Figure 1 here]}

In these circumstances, the precarity of their own working conditions can be seen as a resource that the young founders of SSE projects often implement at the outset to facilitate the consolidation of the entity. In a context of economic crisis, exposure to precarity is even more normalized. Working conditions, or lack thereof, are understood as part of the necessary initial project investment: precarity is considered a resource. It is for this reason that the survey elicited information about the resources used at the beginning of the project. The following table presents an analysis of the main components in the answers to this question, which sheds light on different aspects of the resources necessary to start an SSE project.

\section{[Table 1 here]}

The analysis reveals three dimensions of the resources used to begin an economic activity in the SSE. The first two dimensions are rather predictable and commonplace in the initial stages of any economic activity. They are related to the mobilization of relational capital (starting in a sector in which participants have already worked or collaborated from associationism) and the mobilization of economic capital (investing your own savings or those of close relatives). The most interesting of these results is the appearance of a third dimension which is clearly distinguishable from the others. This group contains aspects such as combining the start of the project with other work to have income to live on, living with parents to be able to dedicate resources to the project and receiving money from friends. Although these items relate to rather different circumstances, they are similar in that they can call be considered precarious and they are ways to respond to a situation of need that is seen to be temporary. They are strategies that rely on the ability to sacrifice and they also imply voluntary exposure to precarious situations in order to be able to continue pushing the project forward.

"In many of these initiatives, people either have significant prior capital (savings, unemployment benefits advances, etc.) or people put in long hours. We've been told many times that if you worked out the price per hour 
in the initial stages, it's a lot of hours for very little in return. There's a key cost in terms of money and/or time that isn't always feasible depending on where you are in your life"

[Participatory session. SSE and feminism researcher]

This notion of 'precarity as a resource' has also appeared in the qualitative findings as one of the main dangers in SSE projects. The special commitment to projects that founding members in particular have, can lead to a sort of self-explotation that runs contrary to the SSE principles. In addition, this phenomena is not exclusive for projects in their early-stages. The "sunk cost fallacy" which means that the time and emotional investment in an organisation makes it harder to abandon (Arkes \& Blumer, 1985) can prolong stagnant situations.

Despite the lack of official data, it would appear that working conditions tend to be better in the SSE than in the conventional economy, even during the economic crisis. However, precarity and selfexploitation play a vital role particularly when launching a project. The women doing this are acutely aware of this type of situation and they often consider this precarity as necessary capital in order to be able to consolidate their projects. There is also a great deal of concern about limiting the precarity of workers, with the result that workers often have better working conditions than the founding partners.

\section{Job satisfaction and commitment}

In addition to objective working conditions, a key aspect in career trajectories is subjective work valuation. It is clear that precarity and income influence the valuation of a job, but other subjective elements are becoming increasingly relevant. In a crisis or post-crisis context with higher turnover, widespread job insecurity and degradation of working conditions, these subjective valuations are becoming more important when explaining career decisions, especially among young people (Lechmann, 2015), who tend to consider their contributions, social impact and shared principles (Karunan, 2007).

The survey asked participants to score 10 aspects of working in the SSE entity on a scale of 1 to 10 . Table 2 shows the results of the analysis of the main components.

\section{[Table 2 here]}

Of the three components which appear in the table, the first includes the items related to how easy it is to balance work with other aspects of life (family, other life commitments and length of working day). The second is made up of valuations related to interest in and stimulation from work, both in relation to the work itself ('Interesting' or 'Creative') and the work environment ('Good working atmosphere'). Finally, the third component includes valuations linked to material conditions ('Good remuneration', 'Stable', 'Possibilities for promotion' and 'Adaptation of the working day')

For each of these dimensions, the average valuation of indexes ${ }^{\mathrm{iv}}$ created by adding the linked items and standardizing them on a scale of 1 to 10 are presented in Table 3. The results clearly show that the most valued aspect of work for young women linked to the SSE is the level of stimulation. 


\section{[Table 3 here]}

This result, similar to that seen above, reflects an idea that was very present in the interviews, discussion groups and participatory sessions: despite the difficulties and situations of precarity, many of the young women in SSE projects are satisfied with and committed to their work. In practically all cases, part of this satisfaction stems from being considered as equals in a project that is consistent with their principles and view of the world.

"The powerful thing about the SSE is the 'willing to'. Separating this from income and economic aspects, there's a will to innovate, influence, and self-criticise about aspects of caregiving and gender that is much greater than in the conventional economy." [Interview. Worker partner]

This 'willing to' is a key element in maintaining the motivation of those involved in the projects, which still do not provide expected working conditions but are more than satisfactory in terms of the possible ways of working with them. On many occasions, this is related to consistency with principles and ideology.

To analyse this component, the women interviewed were asked if they were working in the SSE due to chance or if it was conscious decision to choose a particular economic and social model that was more consistent with their principles. They were asked to score this on a scale from 1 to 10 , with 1 being entirely by chance and 10 being entirely their decision. To see what relationship this has with job satisfaction, the correlation of this question with the different job valuation indexes was analysed.

\section{[Table 4 here]}

The mere fact of considering jobs in the SSE to be stimulating has a strong correlation with the SSE being chosen due to ideological coherence. These results reflect what was seen in the qualitative analysis. However, this correlation does not show the feeling of being more committed, interested and stimulated by a role in a shared and horizontal project which is consistent with workers' own values.

"In my experience, I think you join the SSE for a job that's related to your profession but you end up staying for the dynamics, values and the way it works and not so much for the job itself. Being in a cooperative is complex and management tasks aren't easy. Given the size of cooperatives, professional development in a specific area is limited but there is ample scope for personal and professional development in a broader sense, but not everyone sees it that way." [Interview. Founding partner]

An obvious desire to work differently along with the autonomy and flexibility with which projects allow workers to carry out their duties and manage work in a shared way and therefore reflecting common values and ideology are key elements in maintaining levels of motivation in projects and the personal satisfaction of the people linked to them. 


\section{The gender dimension}

Within the framework of the SSE, there is a clear will to advance in the debates and means of organizations that indicate it is possible to overcome gender inequality in the workplace and propose a labour system that is more respectful of and compatible with all aspects of life. From a feminist economy perspective, the SSE can be considered as a favourable space in which economic activities that respect the 'sustainability of life' can be developed, since the values of the Solidarity Economy focus on economic and social stability, democracy, equality and equity (Mansilla et al., 2014). In the interviews and discussion groups with young women in the SSE, it was revealed that what is important to them is creating caregiving spaces within the SSE, empathetic conflict resolution, and defining measures that create a work-life balance so that any work activity can be compatible with all aspects of life, putting an end to gender roles and patriarchal dynamics. In the participatory sessions, the discussions revealed that the young women in the SSE demonstrate a great commitment to the feminist agenda:

"Our project has always had a feminist aspect and we've been raising awareness and arguing that we have advanced as an organization. We define ourselves as a feminist organization. Internally, we work with a view towards gender, equality measures and co-responsibility. But in the SSE and the business world, even though people want more balance and quality, there is still some way to go such as having women in positions of political representation in the sector and decision-making" [Focus group. Founding partner]

Market inertia, economic viability and even project growth can hinder the implementation of desired caregiving and work-life balance measures. As seen above, the beginning of a project requires more investment of resources but they can also be periods of huge demand. Project responsibility, enthusiasm and commitment to others who are involved may create a self-imposed trap in which there is very little room for movement to be able to apply any measures that allow life to be 'put at the centre'.

"The conditions are better, but I don't know if we really are allowed to try and balance our work and lives outside. I say this because sometimes I think that instead of putting life at the centre, the project sometimes becomes the centre of your life. Putting life in the centre implies taking care of each other, establishing respectful schedules etc. When the project becomes our life, it engulfs us. The big challenge is saying how we are doing it and if they're entrapping us. It does seem that the current business model is heading towards doing the work project, living our own lives and breaking down barriers.!" [Interview. Founding Partner]

To analyse how this position can be applied to entity dynamics and day-to-day practices, the following questions related to the existing gender roles in the SSE entity were included in the survey:

\section{[Table 5 here]}

As noted above, the survey was carried out with a non-probability sample so any frequencies must be interpreted in relation to the survey sample and therefore it is not possible to make direct inferences. However, it is possible to identify some trends that support the results of the qualitative 
analysis. The data gives credence to the idea that SSE organizations, despite being aware of gender discrimination and trying to overcome it, are still affected by masculine and feminine roles. It is noteworthy that the feminine roles are maintained with greater incidence than those associated with masculinity. In SSE organizations it seems easier for women to take on masculinized tasks and roles than vice versa.

Still, the main aim of these questions was to create an index to measure the differences in gender roles within the SEE. The results indicate that there are differences within the SSE when it comes to such daily attitudes and practices. To analyse the determinants of this variance, the index ${ }^{\mathrm{v}}$ was used as a dependent variable in a linear regression model showing different variables of these characteristics of SSE entities $^{\text {vi }}$. The most outstanding result of this model is the positive effect of the entity's age on the existence of gender roles. Figure 2 shows the predicted values of the model based on the age of the SSE entity.

\section{[Figure 2 here]}

The effect of entity age on the existence of gender roles highlights the growing relevance of feminist perspectives in new SSE projects. In other words, other factors aside, the newer the project, the more equalitarian roles are developed within the organization. The most reasonable explanation for this is that the latest wave of feminism had a great impact on young people (Chamberlain, 2017; Dean \& Aune, 2015) and on SSE discourse, and therefore shaped the creation process of new SSE entities. These entities have more naturally incorporated a feminist perspective as a central part of the project from the outset. Unlike older entities, they do not have to deal with already established labour dynamics and roles.

Concerns about gender inequality and the coming together of women in the SSE with a feminist perspective on the idea of work is undeniable. In the discussion groups and participatory sessions, this was also a main concern, also. Furthermore, the data seems to indicate that this concern is particularly present for younger generations and this is reflected in the fact that most new entities have incorporated dynamics to overcome gender roles from the beginning. However, much like for working conditions, the project requirements themselves and the fact that they operate in a market governed by competition and monetary benefit in a context of economic crisis makes it extremely difficult to meet expectations.

\section{Conclusions. Swimming together against the current}

The nature of the SSE as an economic and labour space oriented towards the well-being of people and not just monetary benefits allows for problems of precarity of gender discrimination to move to the fore in economic and labour projects. As has been shown, this does not imply that the SSE succeeds in eliminating these problems. Rather, SSE entities operate in the conventional market and in order to make their projects viable, they need to compete with companies that do not necessarily incorporate these concerns or the costs that they could entail into their planning. The 
context of a crisis makes it more difficult to ensure that projects are viable and this increases the need to make sacrifices in working conditions or ways of ensuring a satisfactory work-life balance.

However, even though objective conditions are not very different from the conventional economy, the experiences and expectations of young woman acquire a new dimension of awareness and commitment. Awareness due to precarious situations or difficulties when reconciling work and personal life are not seen as an unavoidable or alien circumstances but rather a responsibility that must be addressed. There are two reasons for the observed levels of commitment. On the one hand, as seen above, ideology and similar principles are essential to understand options for SSE. On the other hand, shared and horizonal projects give the sensation that workers are not alone and that difficulties and responsibilities are shared. This feeling of coherence and co-responsibility affects experiences and expectations in career transitions in an adverse context: in effect, they are swimming together against the current.

Furthermore, in some cases, responsibility and commitment can also cause contradictory situations of self-exploitation in which the project becomes mixed with life in such a way that instead of putting life at the centre, the project sometimes becomes the centre of your life' (Interview. Working partner). However, despite limitations and obstacles, there is a clear desire to generate egalitarian projects that value caregiving and that prioritize life, which is in line with the principles of the feminist economy. In this case, it has been found that the most recent wave of feminism has had a strong impact on the newest SSE entities, which in turn tend to develop more equalitarian gender roles within the organizations.

However, it is necessary to point out some limitations. From the outset, the global impact of the SSE on career transitions of young women is practically imperceptible for now due to this type of economy being very small. Furthermore, as seen above, in the case of Catalonia, this is an option for women with a specific profile: middle-class with a university education and an associative background. It is also necessary to consider that the nature and implementation of the SSE both in Europe and globally is incredibly unequal. In Latin America, for example, the SSE has developed in popular collectives and communities, some of which are very disadvantaged and often with very strong female leadership (Guerra, 2010; Coque, 2002). This is an area for further research in order to understand the implications of these economic models on career trajectories in different social and economic contexts and to also explore the impact on different social profiles.

As pointed out by the ILO (Borzaga et al., 2017), there is no doubt that the SSE offers some points to consider for future improvements in the world of work. The new global economic crisis as a consequence of COVID-19 may increase vulnerability and uncertainty in young generations and their career trajectories and it would therefore be advisable for public policy to explore ways of strengthening and empowering youth transitions offered by the SSE. 


\section{References}

Aassve, A., Cottini, E., \& Vitali, A. (2013). Youth prospects in a time of economic recession. Demographic Research, 29, 949-962. https://doi.org/10.4054/demres.2013.29.36

Arkes, H. \& Blumer, C. (1985). The psychology of sunk cost. Organizational Behavior and Human Decision Processes, 35 (1), 124-140. https://doi.org/10.1016/0749-5978(85)90049-4

Batchelor, S., Fraser, A., Whittaker, L., \& Li, L. (2020). Precarious leisure: (re)imagining youth, transitions and temporality. Journal of Youth Studies, 23 (1), 93-108. https://doi.org/10.1080/13676261.2019.1710483

Bazeley, P. (2009). Editorial: Integrating Data Analyses in Mixed Methods Research. Journal of Mixed Methods Research, 3(3), 203-207. https://doi.org/10.1177/1558689809334443

Bergeron, S., \& Healy, S. (2015) Beyond the business case: a community economics approach to gender, development and social economy. In P. Utting (Ed.), Social and Solidarity Economy, Beyond the Fringe (pp.72-85). London: Zed Books.

Borzaga, C. (Ed.) (2015) Economia cooperativa: Rilevanza, evoluzione e nuove frontiere della cooperazione italiana. Trento: Euricse Edizioni.

Borzaga, C., Salvatori, G., \& Bodini, R. (2017). The Future of Work - Social and Solidarity Economy and the Future of Work. (Euricse Working Paper for the ILO/ International Labour Office). Geneva: ILO.

Browne, K. (2005). Snowball sampling: using social networks to research non-heterosexual women, International Journal of Social Research Methodology, 8(1), 47-60, DOI: $10.1080 / 1364557032000081663$

Cachón Rodríguez, L. (2004). Las políticas de transición: Estrategia de actores y políticas de empleo juvenil en Europa. Revista de Estudios de Juventud, 65, 51-63.

Cairns, D., Growiec, K., \& de Almeida Alves, N. (2014). Another “Missing Middle"? The marginalised majority of tertiary-educated youth in Portugal during the economic crisis. Journal of Youth Studies, 17(8), 1046-1060. https://doi.org/10.1080/13676261.2013.878789

Cameron, R. (2009). A sequential mixed model research design: Design, analytical and display issues. International Journal of Multiple Research Approaches, 3(2), 140-152, DOI: 10.5172/mra.3.2.140

Carini, C.; Fontanari, E. (2017). Il valore economico e occupazionale dell'economia cooperativa nel 2014, (Euricse Working paper No. 4). Trento: Euricse.

Carrasco, C. Díaz (Eds.) (2017). Economía Feminista. Desafios, propuestas, alianzas. Barcelona: Entrepueblos.

Carrasco, C. (2006). La economía feminista: una apuesta por otra economía. In M. J. Vera (Ed.), 
Estudios sobre género y economía. Madrid: Akal Economía Actual.

Carrasco, C. (2011). La economía del cuidado: planteamiento actual y desafíos pendientes. Revista de Economía Crítica, 11, 205-225.

Chacaltana, Elder and Lee (2020) Youth transitions and lifetime trajectory. (EMPLOYMENT Working Paper No. 253). Geneve: ILO.

Chamberlain, P. (2017). The feminist fourth wave: Affective temporality. The Feminist Fourth Wave: Affective Temporality. Basel: Springer. https://doi.org/10.1007/978-3-319-53682-8

COCETA. (2018). Las mujeres en las cooperativas de trabajo. Estudio sobre la realidad social y laboral de las mujeres en las Cooperativas de Trabajo en España. Madrid: Confederación Española de Cooperativas de Trabajo Asociado.

Coque, J. (2002). Las cooperativas en America Latina: visión histórica general y comentario de algunos países tipo. CIRIEC-España, Revista de Economía Pública, Social y Cooperativa, 43, 145172

Craig, L. (2012). Contemporary motherhood: The impact of children on adult time. Contemporary Motherhood: The Impact of Children on Adult Time. 13 (3): 358-359.

https://doi.org/10.1111/j.1365-2206.2008.00568.x

Dean, J., \& Aune, K. (2015). Feminism Resurgent? Mapping Contemporary Feminist Activisms in Europe. Social Movement Studies, 14 (4), 375-395.

https://doi.org/10.1080/14742837.2015.1077112

Dietrich, H., \& Möller, J. (2016). Youth unemployment in Europe - business cycle and institutional effects. International Economics and Economic Policy, 13, 5-25.

https://doi.org/10.1007/s10368-015-0331-1

Echaves, A., \& Echaves, C. (2017). Jóvenes aún más precarios: crisis económica y desigualdad laboral en España. Cuadernos de Investigación En Juventud, (2).

https://doi.org/10.22400/cij.2.e007

Federici, S. (2018). El patriarcado del salario. Críticas feministas al marxismo. Madrid: Traficantes de Sueños. https://doi.org/10.35428/cds.v0i8.125

Fenton, S., \& Dermott, E. (2006). Fragmented careers?: Winners and losers in young adult labour markets. Work, Employment and Society, 20(2), 205-221. https://doi.org/10.1177/0950017006064111

Fonteneau, B., Neamtan, N., Wanyama, F., Pereira, L., Poorter, M., \& Borzaga, C. (2011). Economía Social y Solidaria: nuestro camino común hacia el trabajo decente. Turin: Centro Internacional de Formación de la OIT.

France, A. (2016). Understanding youth in the global economic crisis. In Understanding Youth in the Global Economic Crisis. Bristol: Bristol University Press. https://doi.org/10.2307/j.ctt1t89fwf

Guerra, P. (2010). La Economía Solidaria en Latinoamérica. Papeles de relaciones ecosociales y cambio global, 110, 67-76. 
Huysentruyt, M. (2014). Women 's Social Entrepreneurship and Innovation. OECD Local Economic and Employment Development (OECD-LEED Working Papers, 2014/01), 1-24. OECD.

Johnson, R., J. Onwuegbuzie, A., \& A Turner, L. (2007). Toward a Definition of Mixed Methods Research. Journal of Mixed Methods Research, 1, 112-133. Journal of Mixed Methods Research. 1(2): 112-133. https://doi.org/10.1177/1558689806298224

Kalogeraki, S., Papadaki, M., \& Pera Ros, M. (2018). Exploring the Social and Solidarity Economy Sector in Greece, Spain, and Switzerland in Times of Crisis. American Behavioral Scientist, 62(6), 856-874. https://doi.org/10.1177/0002764218768862

Karunan, V. P. (2007). Adolescents and Civil Engagement: Social Entrepreneurship and Young People. (Learning Series No. 3). New York: United Nations Children's Fund (UNICEF).

Leccardi, C. (2012). Young people's representations of the future and the acceleration of time. A generational approach. Diskurs Kindheits- Und Jugendforschung, 1, 59-73

Lechmann, D. S. J. (2015). Können Arbeitsbedingungen das „return-to-entrepreneurship puzzle“ erklären? Journal for Labour Market Research, 48(4), 271-286. https://doi.org/10.1007/s12651-015-0172-y

Mansilla, E., Grenzner, J. G., \& Alberich, S. (2014). Femení Plural. Les dones a l'economia cooperativa. Barcelona: Diputació de Barcelona.

Miguel Carmo, R., Cantante, F., \& de Almeida Alves, N. (2014). Time projections: Youth and precarious employment. Time \& Society, 23(3), 337-357. https://doi.org/10.1177/0961463X14549505

Millán-Vázquez de la Torre, M. G., Santos-Pita, M. D. P., \& Pérez-Naranjo, L. M. (2015). Análisis del mercado laboral femenino en España: Evolución y factores socioeconómicos determinantes del empleo. Papeles de Poblacion, 21(84), 197-225.

Monzón, J. L., \& Chaves, R. (2012). The Social Economy in the European Union. Brussels: European Economic and Social Committee. https://doi.org/10.2864/19534

Monzón, J. L., \& Chaves, R. (2016). CIRIEC: Recent Evolutions of the Social Economy in the European Union, 25 (2), 226-230. https://doi.org/10.3935/rsp.v25i2.1543

Moreno, S. (2013). Gènere. Una anàlisi de les transicions juvenils des de la perspectiva de gènere. In Serracant. P. (Ed.) Enquesta a la joventut de Catalunya 2012. (pp 157-217). Barcelona: Direcció General de Joventut.

Nind, M. (2011). Participatory data analysis: A step too far? Qualitative Research, 11(4), 349-363 https://doi.org/10.1177/1468794111404310

Nordström Skans, O. (2011). Scarring effects of the first labor market experience. (IZA Discussion Paper- IZA DP No. 5565). Bonn: Institute for the Study of Labor.

Nyström, K. (2019). Working for an entrepreneur: heaven or hell? Small Business Economics, (June). https://doi.org/10.1007/s11187-019-00276-0 
Onyx, J., \& Maclean, M. (1996). Careers in the third sector. Nonprofit Management and Leadership, 6 (4), 331-345. https://doi.org/doi:10.1002/nml.4130060404

Pastore, F. (2015). The youth experience gap : explaining national differences in the school-to-work transition. Basel: Springer.

Pigou, A. C. (1920). The Economics of Welfare. London: Palgrave Classics in Economics..

Py, J., \& Berthélemy, S. (2019). Women-led social enterprises : a European Study. Paris: Empow'her.

Roberts, S. (2011). Beyond "neet" and "tidy" pathways: Considering the "missing middle" of youth transition studies. Journal of Youth Studies, , 14i (1), 21-39. https://doi.org/10.1080/13676261.2010.489604

Schmillen, A., \& Umkehrer, M. (2017). The scars of youth: Effects of early-career unemployment on future unemployment experience. International Labour Review, 156 (3-4), 465-494 https://doi.org/10.1111/ilr.12079

Serracant, P. (2015). The Impact of the Economic Crisis on Youth Trajectories: A Case Study from Southern Europe. Young, , 23(1), 39-58. https://doi.org/10.1177/1103308814557398

Utting, P. (2015) Social and Solidarity Economy: Beyond the Fringe. London: Zed Books.

Verd, J. M., Barranco, O., \& Bolíbar, M. (2019). Youth unemployment and employment trajectories in Spain during the Great Recession: what are the determinants? Journal for Labour Market Research, 53 (1). https://doi.org/10.1186/s12651-019-0254-3

Walsh, L., Keary, A., \& Gleeson, J. (2019). Non-linear Transitions: An Intergenerational Longitudinal Study of Today's Young Women in Education and Work. Young, 27 (5), 468-485. https://doi.org/10.1177/1103308818817632

Waring, M. (1988) If Women counted. A New Feminist Economics. San Francisco: Harper Collins Publishers.

Whyte, W. F. (1989). Advancing scientific knowledge through participatory action research. Sociological Forum, 4, 367-385. https://doi.org/10.1007/BF01115015

Woodman, D. (2013). Researching "ordinary" young people in a changing world: The sociology of generations and the "missing middle" in youth research. Sociological Research Online, 18 (1), 179-190. https://doi.org/10.5153/sro.2868

Zeuli, K. \& Deller, S. (2007). Measuring the Local Economic Impact of Cooperatives. Journal of Rural Cooperation, 35(1), 1-17. 

i One example is the Social Balance Survey (http://mercatsocial.xes.cat/ca/eines/balancsocial/) promoted by the Solidarity Economy Network, which annually collects data on working conditions from more than 200 entities in the social economy. There is also the Government of Catalonia's Register of Cooperatives but it is difficult to determine how up-to-date it is. ii The index has been built based on four variables: Type of contract, weekly hours in contract, multiple jobs and income. Each of the values of these variables has been assigned a numerical value that is added to create the index. For 'Type of contract': $0=$ 'No contract', 1 = 'Freelance', $2=$ 'Temporary contract', $4=$ 'Permanent contract'. For 'Weekly hours': $0=$ 'Less than 20', 1 = 'From 20 to 34 hours', 2 = '35 hours or more'. For 'Multiple jobs': 0 = 'Multiple jobs but main job is outside the SSE entity', 1 = 'Multiple jobs with main job in the SSE', 2 = 'One job in the SSE entity'. For 'Income': $0=$ 'No income', 1 = 'Less than $900 €^{\prime}, 2=$ 'Between 900 and 1,200€', $3=$ 'Between 1,201 and 1,500€', $4=$ More than 1,500€'. The result is an index with a value from 0 to 11 .

iii Bilateral correlation between 'Working conditions index' and 'Age of the SSE entity' is $r=0.185$ (sig. 0.004 and $N=245$ ) iv The reliability of the indexes has been checked through Cronbach's Alpha: 'Ability to balance' $\alpha=0.77$; 'Stimulation' $\alpha=0.72$; and 'Material conditions' $\alpha=0.61$.

$\checkmark$ To create the index, 0 was assigned for 'strongly disagree', 1 for 'disagree', 2 for 'neither agree nor disagree', 3 for 'agree' and 4 for 'strongly agree' for each question. The scale was standardized to a range from 0 to 10 , with 0 being the least and 10 the most to indicate the existence of gender roles in the entity. Index reliability has been tested obtaining a Cronbach's Alpha $\alpha=0.65$.

vi The independent variables used were the year the entity was founded, the feminization index (the percentage of women in the entity), the size of the entity (the total number of workers), its legal status (being a cooperative as opposed to other forms) and the activity sector (customer service against others). 